\title{
A Natura 2000 területek természetvédelmi jelentősége az agrártájban: esettanulmány a lökösházi Turai-gyep tájban betöltött szerepéröl
}

\author{
Bozó László ${ }^{1,2 *}$, Rozgonyi János² és Csathó András István ${ }^{3}$ \\ ${ }^{1}$ Eötvös Loránd Tudományegyetem, Állatrendszertani és Ökológiai Tanszék, \\ 1117 Budapest, Pázmány Péter sétány 1/C \\ ${ }^{2}$ Dél-békési Természetvédelmi és Madártani Egyesület, 5744 Kevermes, Jókai u. 61. \\ ${ }^{3}$ Független kutató, 5830 Battonya, Somogyi Béla u. 42/A \\ *E-mail: bozolaszlo91@gmail.com
}

\begin{abstract}
Összefoglaló: Békés megye déli részén az agrárterületek a teljes külterület közel 90\%-át teszik ki, míg a természetvédelmileg értékes élőhelyek csak szigetszerűen, kis fragmentumokban maradtak fenn. Dolgozatunkban ebből a földrajzi régióból, a lőkösházi Turai-gyep Natura 2000 területröl közlünk madártani és növénytani adatokat a 2010 és 2020 közötti időszakból. A terepi munka során összesen 170 madárfaj jelenlétét mutattuk ki a területről, amelyek közül 57 faj rendszeresen vagy alkalmilag fészkelt a gyepen. A fészkelők között több olyan védett és fokozottan védett faj is akad, amely a térség más részein nem költ. A botanikai adatgyüjtés során is előkerültek védett, a tájban egyébként igen ritka fajok, míg egy fokozottan védett rovarfaj (nagy szikibagoly - Gortyna borelii lunata) előfordulása szintén a terület fontosságát jelzi. Eredményeink egyértelmúen jelzik, hogy a még megmaradt természetes élőhelyfoltok kulcsfontosságúak a térség biodiverzitásának fenntartásában, eltünésük több faj lokális-regionális kipusztulását okozná.
\end{abstract}

Kulcsszavak: élőhely-fragmentum, mezőgazdasági területek, vízimadarak, szikesek, Csanádi-hát, nagy szikibagoly

\section{Bevezetés}

Az Európai Unió által az 1979-es Madárvédelmi Irányelv és az 1992-es Élőhelyvédelmi Irányelv alapján létrehozott Natura 2000 olyan összefüggő ökológiai hálózat, amely közösségi jelentőségü természetes élőhelytípusok, illetve vadon élő állat- és növényfajok védelmén keresztül biztosítja a biológiai sokféleség megóvását, és hozzájárul kedvező természetvédelmi helyzetük fenntartásához és helyreállításához (European Commission 2000a, 2000b, Evans 2012, http1). A Natura 2000 hálózat részben a védett természeti területek már meglévő hálózatára épült (a jelölt területek 39\%-a), de jelenleg még védelem alatt nem álló területek is 
részét képezik. A magyarországi Natura 2000 területeket 46 közösségi jelentőségü élőhelytípus, 36 növény-, 91 madár- és 105 egyéb állatfaj jelentős hazai állományai figyelembevételével jelölték ki (http1). Jelenleg Magyarországon összesen 479 különleges természetmegörzési terület és 56 különleges madárvédelmi terület található, amelyek mintegy 1,95 millió hektárt tesznek ki, ami az ország területének 21,39\%-a (http1).

A különleges természetmegőrzési területek kijelölésének alapját a közösségi szempontból jelentős fajok és élőhelytípusok képezik (Evans 2012). Az Európai Bizottság által 2007. november 13-án jóváhagyott különleges természetmegőrzési területek között számos Békés megyei terület is megtalálható, köztük olyanok is, amelyek korábban nem tartoztak a védett természeti területek közé (http1). Ezek egyike a Lőkösháza külterületén található Turai-gyep is, amely a HUKM20010 kódjelü, Gyula-szabadkígyósi gyepek nevet viselő Natura 2000 terület részét képezi (http2). A Gyula-szabadkígyósi gyepek összterülete 10634 hektár, ám ezen terület jelentős része a Körös-Maros Nemzeti Park törzsterületét képező védett és fokozottan védett Kígyósi-pusztát foglalja magába. A lőkösházi területegység kiterjedése megközelítőleg 200 hektár, amelyböl legalább 80 hektáron mind a mai napig szántóföldi növénytermesztés zajlik, és csak kb. 120 hektáron találhatunk pannon szikes gyepet és mocsarat (Natura 2000 élöhelykód: 1530), valamint síksági pannon löszgyepet (élőhelykód: 6250). Az utóbbi, megközelítőleg 120 hektáros területet nevezik Turai-gyepnek, amely Dél-Békés egyik legnagyobb öszszefüggő gyepterülete (Bozó 2018); nagyobb kiterjedésü, mint a szintén ebben a térségben található - az ország egyik legértékesebb löszpusztagyepjeként számon tartott - Tompapusztai-löszgyep (Csathó 1986, 2005, Csathó és Csathó 2009). Békés megye déli részén a szántóterületek a teljes külterület közel 90\%-át teszik ki, míg természetközeli élőhelyeket, így gyepeket, erdőket településenként változó, 0,2-8,7\% közötti arányban találhatunk csupán (Hevesi 2005). A Turai-gyep egy hajdani Maros-mederben húzódik, ezért csapadékos időjárás esetén, illetve a kora tavaszi időszakban jellemzően vízállások borítják a felszínét (Bozó 2017a, 2017b, 2018).

Jelen dolgozatban a lökösházi Turai-gyep példáján keresztül szeretnénk rávilágítani a Natura 2000 hálózat jelentőségére az agrártájakban, hiszen a kistájban az erdők, vizes élőhelyek és gyepek - amelyek jelentős része sajnos nem tekinthető természetesnek - a területnek csak megközelítőleg 10\%-át teszik ki. A kis kiterjedésű természetes élőhelyeket, így a hajdani löszpuszták őrzőit, a mezsgyéket és kunhalmokat, vagy éppen az itt tárgyalt szikes területeket viszont nagy fajgazdagság jellemzi (Csathó 2009, Deák et al. 2016, Bede és Csathó 2019). Kis kiterjedésük miatt azonban ezek a területek általában nagyon sérülékenyek, hosszú távú védelmük jelenleg nem megoldott. 


\section{Anyag és módszer}

Dolgozatunkban a Lőkösháza közigazgatási területéhez tartozó Turai-gyepet (WGS $46.44608^{\circ} ; 21.28597^{\circ}$ ) vizsgáltuk. A területen a szántóföldek mellett a pannon szikes gyep és mocsár vegetáció dominál, de találhatunk itt síksági pannon löszgyepet és nagy kiterjedésű nádasokat is.

Munkánk során elsősorban madártani és botanikai adatgyüjtést végeztünk, de a terepmunka során előkerült egyéb, érdekesebb állatfajok előfordulását is feljegyeztük.

A Turai-gyep madártani felmérése 2010-ben kezdődött el, azóta összesen 143 alkalommal végeztünk a Natura 2000 terület egészét érintő madártani felmérést. A megfigyelési alkalmak számának havi eloszlása a következő: január: 4, február: 3 , március: 11 , április: 27 , május: 17 , június: 18 , július: 28 , augusztus: 14 , szeptember: 10, október: 7, november: 3 és december: 1. Legintenzívebben a március közepe és július közepe közötti időszakban vizsgáltuk a Turai-gyepet, ami egybeesik azokkal az időszakokkal, amikor a terület bizonyos részeit belvíz borította. A november közepe és február vége közötti téli periódusban a megfigyelések száma jelentősen kevesebb volt, mert a gyep földutak rossz állapota miatt nehezen volt megközelíthető. A megfigyeléseket minden esetben kerékpárról, illetve gyalogos terepbejárással végeztük, kézitávcső, fényképezőgép, valamint alkalmanként nagy nagyítású spektív segítségével. A legtöbb madárfajról (különös tekintettel a ritka fajokra) fotódokumentáció is készült. Adatbázisunkban egy adatnak egy megfigyelési nap egy adott madárfajra vonatkozó összesített példányszáma számít. A területen a 11 vizsgált évből ötben a március és július közötti időszakban jelentősebb belvíz gyült össze a laposokban. Tanulmányunkban ezeket az éveket $(2010,2013,2017,2019,2020)$ tekintjük belvizes éveknek. A legmélyebb részeken a többi évben is jelen volt kis kiterjedésủ vízállás.

Dolgozatunkban először a fészkelö, majd az átvonuló és telelő madárfajokkal foglalkozunk, majd ezt követően az érdekesebb botanikai adatokat említjük meg. Adatainkat összehasonlítjuk a térség más, hasonló élőhelyeivel foglalkozó publikációk eredményeivel. Mind a madarak, mind a növények közül azokat a fajokat tárgyaljuk részletesen, amelyek országosan vagy regionálisan kiemelt természeti értéknek számítanak, így Magyarországon kisszámú, veszélyeztetett állományú fészkelők, vagy költésük, vonuláskor vagy télen megfigyelt egyedeik Dél-Békésben egyedülállónak, érdekesnek számítanak.

A madarak tudományos elnevezésekor az IOC World Bird List 9.2 verzióját használtuk (Gill és Donsker 2019), míg a magyar nevezéktan esetében Hadarics és Zalai (2008) munkája volt a mérvadó. A növények nevezéktana Király (2009) munkáját követi. 


\section{Eredmények}

Az eredmények bemutatását a fészkelő madárfajok általános bemutatásával kezdjük, majd ezt követően következik néhány természetvédelmi szempontból értékes költő faj részletesebb bemutatása. Ezután kerül sor az átvonuló és telelő madarak, illetve a kiemelt növénytani értékek leírására.

\section{Fészkelö madárfajok}

A tárgyalt területen 2010 és 2020 között összesen 57 madárfaj fészkelt bizonyítottan, vagy volt alaposan valószínüsíthető fészkelése, annak ellenére, hogy a fészek vagy a fiókák nem kerültek elö. Ez a 34\%-a a valaha itt megfigyelt 170 madárfajnak (1. táblázat). Ezen fajok az alábbi élőhelytípusokhoz kötődnek: nádas (14 faj), mocsár ( 9 faj), fasorok, erdőfoltok, magányos fák, cserjék (22 faj), nyílt, száraz gyep (9 faj) és belvizes szántó ( 3 faj). Az említett madárfajok közül 41 védett, kilenc fokozottan védett és hét nem áll védelem alatt. A legnagyobb fészkelöállománnyal a foltos nádiposzáta rendelkezik (kb. 30 pár).

\section{Természetvédelmi szempontból értékes fészkelö madárfajok}

Nyári lúd (Anser anser)

Elöször 2013-ban költött a gyep mellett egy belvizes szántón kialakult sásos foltban. A szülőket és a három fiatalt legkésőbb július 12-én figyeltük meg a területen. 2015-ben, 2016-ban és 2017-ben csak az öreg madarakat lehetett megfigyelni a költési időszakban, fiatalokat nem láttunk; mindhárom évben a gyep középső részén lévő nádasban lehetett a fészkük.

Böjti réce (Spatula querquedula)

Bizonyítottan csak 2013-ban költött egy pár a gyep melletti belvizes szántón kialakult sásos foltban. Ekkor egy tojót és három fiatal egyedet figyeltünk meg (2013. június 5.).

Bölömbika (Botaurus stellata)

A 2010 és 2020 közötti időszakban csupán egyetlen évben, 2017-ben nem költött a területen. A fészkelő párok száma a vizek kiterjedésének függvényében egy és három pár között változik. Három különböző helyen csak 2013-ban észleltük a fajt, jellemzően két, egymástól kb. egy kilométer távolságra elhelyezkedő nádasban költenek.

Fürj (Coturnix coturnix)

A tájban ez az egyike azon természetes gyepeknek, ahol fészkel a faj. 2010 óta stabil állománya él a területen, a gyepen 2-3 kakast lehet rendszeresen hallani a költési időszakban. 
1. táblázat. A Turai-gyepen 2010 és 2020 között megfigyelt madarak listája, azok státusza és a megfigyelési alkalmak száma. A státusz esetében az alábbi betűjelzéseket használjuk: $\mathrm{F}=$ fészkelö; Á = rendszeres átvonuló; KÁ = kóborló átvonuló (kevesebb, mint öt megfigyelési adat); $\mathrm{T}$ = téli vendég; RV = rendszeres, az év bármely szakaszában megfigyelhető vendég, ami nem költ a területen.

\begin{tabular}{|c|c|c|c|}
\hline Faj & Tudományos név & Státusz & Adatok száma \\
\hline \multicolumn{4}{|l|}{ Fácánfélék - Phasianidae } \\
\hline Fürj & Coturnix coturnix & F, Á & 44 \\
\hline Fácán & Phasianus colchicus & $\mathrm{F}$ & 141 \\
\hline \multicolumn{4}{|l|}{ Récefélék - Anatidae } \\
\hline Nyári lúd & Anser anser & $\mathrm{F}, \mathrm{A}$ & 15 \\
\hline Nagy lilik & Anser albifrons & Á & 4 \\
\hline Bütykös hattyú & Cygnus olor & KÁ & 1 \\
\hline Kendermagos réce & Mareca strepera & KÁ & 1 \\
\hline Fütyülő réce & Mareca penelope & Á & 6 \\
\hline Tökés réce & Anas platyrhynchos & $\mathrm{F}, \mathrm{A}$ & 97 \\
\hline Kanalas réce & Spatula clypeata & $\mathrm{F}, \mathrm{A}$ & 19 \\
\hline Nyílfarkú réce & Anas acuta & KÁ & 1 \\
\hline Böjti réce & Spatula querquedula & $\mathrm{F}, \mathrm{A}$ & 28 \\
\hline Csörgő réce & Anas crecca & Á & 17 \\
\hline Cigányréce & Aythya nyroca & Á & 5 \\
\hline \multicolumn{4}{|l|}{ Vöcsökfélék - Podicipedidae } \\
\hline Kis vöcsök & Tachybaptus ruficollis & KÁ & 3 \\
\hline \multicolumn{4}{|l|}{ Galambfélék - Columbidae } \\
\hline Parlagi galamb & $\begin{array}{c}\text { Columba livia forma } \\
\text { domestica }\end{array}$ & $\mathrm{RV}$ & 142 \\
\hline Örvös galamb & Columba palumbus & $\mathrm{F}, \mathrm{A}$ & 129 \\
\hline Kék galamb & Columba oenas & Á, T & 32 \\
\hline Balkáni gerle & Streptopelia decaocto & RV & 141 \\
\hline Vadgerle & Streptopelia turtus & $\mathrm{F}, \mathrm{A}$ & 84 \\
\hline \multicolumn{4}{|c|}{ Lappantyúfélék - Caprimulgidae } \\
\hline Lappantyú & Caprimulgus europaeus & KÁ & 1 \\
\hline \multicolumn{4}{|l|}{ Sarlósfecskefélék - Apodidae } \\
\hline Sarlósfecske & Apus apus & Á & 16 \\
\hline \multicolumn{4}{|l|}{ Kakukkfélék - Cuculidae } \\
\hline Kakukk & Cuculus canorus & $\mathrm{F}$ & 75 \\
\hline \multicolumn{4}{|l|}{ Guvatfélék - Rallidae } \\
\hline Guvat & Rallus aquaticus & F, Á & 38 \\
\hline Pettyes vízicsibe & Porzana porzana & $\mathrm{F}, \mathrm{A}$ & 8 \\
\hline
\end{tabular}


1. táblázat (folytatás). A Turai-gyepen 2010 és 2020 között megfigyelt madarak listája, azok státusza és a megfigyelési alkalmak száma. A státusz esetében az alábbi betüjelzéseket használjuk: $\mathrm{F}=$ fészkelö; Á = rendszeres átvonuló; KÁ = kóborló átvonuló (kevesebb, mint öt megfigyelési adat); $\mathrm{T}$ = téli vendég; RV = rendszeres, az év bármely szakaszában megfigyelhető vendég, ami nem költ a területen.

\begin{tabular}{cccc}
\hline Faj & Tudományos név & Státusz & Adatok száma \\
\hline Vízityúk & Gallinula chloropus & F & 14 \\
Szárcsa & Fulica atra & F & 20
\end{tabular}

Darufélék - Gruidae

Daru

Grus grus

Á

18

Gólyafélék - Ciconiidae

Fehér gólya

Ciconia ciconia

RV

Fekete gólya

Ciconia nigra

Á

4

Íbiszfélék - Threskiornithidae

Kanalasgém

Platalea leucorodia

KÁ

6

Gémfélék - Ardeidae

Bölömbika
Törpegém
Bakcsó
Üstökösgém
Szürke gém
Vörös gém
Nagy kócsag
Kis kócsag

Botaurus stellaris
Ixobrychus minutus
Nycticorax nycticorax
Ardeola ralloides
Ardea cinerea
Ardea purpurea
Ardea alba

F 55

Egretta garzetta

F

2

KÁ 3

KÁ 1

Kárókatona-félék -

Phalacrocoracidae

Kárókatona

Phalacrocorax carbo

KÁ

Á

Á

Á

Gulipánfélék - Recurvirostridae

Gulipán

Gólyatöcs

Lilefélék - Charadriidae

Kis lile
Parti lile
Aranylile
Ezüstlile
Bíbic

Recurvirostra avosetta
Himantopus himantopus

F, Á

F, Á
F, Á

Charadrius hiaticula

Pluvialis apricaria

Pluvialis squatarola

Vanellus vanellus
KÁ

Á

KÁ

F, Á 29 20

1 29 29 1 8 1 111 
1. táblázat (folytatás). A Turai-gyepen 2010 és 2020 között megfigyelt madarak listája, azok státusza és a megfigyelési alkalmak száma. A státusz esetében az alábbi betűjelzéseket használjuk: $\mathrm{F}=$ fészkelö; Á = rendszeres átvonuló; KÁ = kóborló átvonuló (kevesebb, mint öt megfigyelési adat); $\mathrm{T}$ = téli vendég; $\mathrm{RV}$ = rendszeres, az év bármely szakaszában megfigyelhető vendég, ami nem költ a területen.

\begin{tabular}{|c|c|c|c|}
\hline Faj & Tudományos név & Státusz & Adatok száma \\
\hline \multicolumn{4}{|l|}{ Szalonkafélék - Scolopacidae } \\
\hline Havasi partfutó & Calidris alpina & Á & 5 \\
\hline Sarlós partfutó & Calidris ferruginea & KÁ & 1 \\
\hline Temminck-partfutó & Calidris temminckii & KÁ & 1 \\
\hline Apró partfutó & Calidris minuta & KÁ & 5 \\
\hline Réti cankó & Tringa glareola & Á & 36 \\
\hline Erdei cankó & Tringa ochropus & Á & 17 \\
\hline Billegetőcankó & Actitis hypoleucos & KÁ & 2 \\
\hline Piroslábú cankó & Tringa totanus & $\mathrm{F}, \mathrm{A}$ & 28 \\
\hline Füstös cankó & Tringa erythropus & Á & 16 \\
\hline Szürke cankó & Tringa nebularia & Á & 16 \\
\hline Tavi cankó & Tringa stagnatilis & Á & 5 \\
\hline Nagy goda & Limosa limosa & KÁ & 2 \\
\hline Kis póling & Numenius phaeopus & Á & 13 \\
\hline Nagy póling & Numenius arquata & Á & 6 \\
\hline Nagy sárszalonka & Gallinago media & Á & 7 \\
\hline Kis sárszalonka & Lymnocryptes minimus & Á & 6 \\
\hline Sárszalonka & Gallinago gallinago & F, Á & 27 \\
\hline Pajzsoscankó & Philomachus pugnax & Á & 21 \\
\hline \multicolumn{4}{|l|}{ Sirályfélék - Laridae } \\
\hline Dankasirály & $\begin{array}{l}\text { Chroicocephalus } \\
\text { ridibundus }\end{array}$ & Á & 14 \\
\hline Sárgalábú/Sztyeppi sirály & $\begin{array}{l}\text { Larus michahellis/L. } \\
\quad \text { cachinnans }\end{array}$ & Á & 25 \\
\hline Kacagócsér & Gelochelidon nilotica & KÁ & 1 \\
\hline Kormos szerkő & Chlidonias niger & KÁ & 2 \\
\hline Fattyúszerkő & Chlidonias hybridus & Á & 4 \\
\hline Fehérszárnyú szerkő & Chlidonias leucopterus & KÁ & 1 \\
\hline \multicolumn{4}{|l|}{ Bagolyfélék - Strigidae } \\
\hline Erdei fülesbagoly & Asio otus & $\mathrm{F}$ & 2 \\
\hline Réti fülesbagoly & Asio flammeus & $\mathrm{F}, \mathrm{T}$ & 12 \\
\hline
\end{tabular}


1. táblázat (folytatás). A Turai-gyepen 2010 és 2020 között megfigyelt madarak listája, azok státusza és a megfigyelési alkalmak száma. A státusz esetében az alábbi betüjelzéseket használjuk: $\mathrm{F}$ = fészkelö; Á = rendszeres átvonuló; KÁ = kóborló átvonuló (kevesebb, mint öt megfigyelési adat); $\mathrm{T}$ = téli vendég; $\mathrm{RV}$ = rendszeres, az év bármely szakaszában megfigyelhető vendég, ami nem költ a területen.

\begin{tabular}{|c|c|c|c|}
\hline Faj & Tudományos név & Státusz & Adatok száma \\
\hline \multicolumn{4}{|l|}{ Halászsasfélék - Pandionidae } \\
\hline Halászsas & Pandion haliaetus & KÁ & 1 \\
\hline \multicolumn{4}{|c|}{ Vágómadárfélék - Accipitridae } \\
\hline Rétisas & Haliaeetus albicilla & $\mathrm{T}$ & 2 \\
\hline Parlagi sas & Aquila heliaca & RV & 35 \\
\hline Békászó sas & Clanga pomarina & Á & 5 \\
\hline Barna kánya & Milvus migrans & KÁ & 2 \\
\hline Barna rétihéja & Circus aeruginosus & $\mathrm{F}, \mathrm{A}$ & 123 \\
\hline Kékes rétihéja & Circus cyaneus & Á, T & 15 \\
\hline Fakó rétihéja & Circus macrourus & Á & 8 \\
\hline Hamvas rétihéja & Circus pygargus & Á & 10 \\
\hline Pusztai ölyv & Buteo rufinus & Á & 7 \\
\hline Egerészölyv & Buteo buteo & RV & 142 \\
\hline Gatyás ölyv & Buteo lagopus & KÁ & 2 \\
\hline Darázsölyv & Pernis apivorus & KÁ & 4 \\
\hline Karvaly & Accipiter nisus & RV & 50 \\
\hline Héja & Accipiter gentilis & Á & 3 \\
\hline \multicolumn{4}{|l|}{ Bankafélék - Upupidae } \\
\hline Búbosbanka & Upupa epops & Á & 21 \\
\hline \multicolumn{4}{|l|}{ Gyurgyalagfélék - Meropidae } \\
\hline Gyurgyalag & Merops apiaster & Á & 19 \\
\hline \multicolumn{4}{|l|}{ Szalakótafélék - Coraciidae } \\
\hline Szalakóta & Coracias garrulus & $\mathrm{F}$ & 9 \\
\hline \multicolumn{4}{|l|}{ Harkályfélék - Picidae } \\
\hline Fekete harkály & Dryocopus martius & KÁ & 1 \\
\hline Zöld küllö & Picus viridis & $\mathrm{F}$ & 33 \\
\hline Nagy fakopáncs & Dendrocopos major & $\mathrm{F}$ & 68 \\
\hline Nyaktekercs & Jynx torquilla & KÁ & 1 \\
\hline \multicolumn{4}{|l|}{ Sólyomfélék - Falconidae } \\
\hline Vörös vércse & Falco tinnunculus & $\mathrm{F}, \mathrm{A}$ & 136 \\
\hline Kék vércse & Falco vespertinus & $\mathrm{F}, \mathrm{A}$ & 39 \\
\hline Kabasólyom & Falco subbuteo & RV & 25 \\
\hline
\end{tabular}


1. táblázat (folytatás). A Turai-gyepen 2010 és 2020 között megfigyelt madarak listája, azok státusza és a megfigyelési alkalmak száma. A státusz esetében az alábbi betűjelzéseket használjuk: $\mathrm{F}=$ fészkelő; $\mathrm{A}=$ rendszeres átvonuló; $\mathrm{KÁ}=$ kóborló átvonuló (kevesebb, mint öt megfigyelési adat); $\mathrm{T}$ = téli vendég; $\mathrm{RV}=$ rendszeres, az év bármely szakaszában megfigyelhető vendég, ami nem költ a területen.

\begin{tabular}{cccc}
\hline Faj & Tudományos név & Státusz & Adatok száma \\
\hline Kis sólyom & Falco columbarius & $\mathrm{T}$ & 3 \\
Kerecsensólyom & Falco cherrug & $\mathrm{RV}$ & 13 \\
Sárgarigófélék - Oriolidae & & & \\
Sárgarigó & Oriolus oriolus & F, Á & 79
\end{tabular}

Gébicsfélék - Laniidae

Nagy örgébics

Kis örgébics

Tövisszúró gébics

Varjúfélék - Corvidae

Szarka
Csóka
Vetési varjú
Dolmányos varjú
Holló

Cinegefélék - Paridae

\section{Széncinege}

Kék cinege

Függőcinege-félék - Remizidae

Függőcinege

Pacsirtafélék - Alaudidae

Mezei pacsirta
Búbospacsirta
Erdei pacsirta

Barkóscinege-félék - Panuridae

Barkóscinege

Nádiposzáta-félék - Acrocephalidae

Foltos nádiposzáta
Fülemülesitke
Cserregő nádiposzáta
Énekes nádiposzáta
Nádirigó

Lanius excubitor

Lanius minor

Lanius collurio

Pica pica

Corvus monedula

Corvus frugilegus

Corvus cornix

Corvus corax

Parus major

Cyanistes caeruleus

Remiz pendulinus

Alauda arvensis

Galerida cristata

Lullula arborea

Panurus biarmicus

Acrocephalus

schoenobaenus

Acrocephalus melanopogon

Acrocephalus scirpaceus

Acrocephalus palustris

Acrocephalus arundinaceus
Á, T

$\mathrm{F}$

F, Á

F

F, Á

Á

$\mathrm{F}$

RV

RV

Á, T

Á

F, Á

Á

Á

KÁ 3

F, Á 95

KÁ 1

F, Á 64

F, Á

51

F, Á

64 
1. táblázat (folytatás). A Turai-gyepen 2010 és 2020 között megfigyelt madarak listája, azok státusza és a megfigyelési alkalmak száma. A státusz esetében az alábbi betüjelzéseket használjuk: $\mathrm{F}$ = fészkelö; Á = rendszeres átvonuló; KÁ = kóborló átvonuló (kevesebb, mint öt megfigyelési adat); $\mathrm{T}$ = téli vendég; RV = rendszeres, az év bármely szakaszában megfigyelhető vendég, ami nem költ a területen.

\begin{tabular}{cccc}
\hline Faj & Tudományos név & Státusz & Adatok száma \\
\hline Kerti geze & Hippolais icterina & Á & 5 \\
Tücsökmadárfélék - Locustellidae & & & \\
Réti tücsökmadár & Locustella naevia & F, Á & 12 \\
Nádi tücsökmadár & Locustella luscinioides & F, Á & 75 \\
Fecskefélék - Hirundinidae & & & \\
Partifecske & Riparia riparia & RV & 36 \\
Füsti fecske & Hirundo rustica & RV & 119 \\
Molnárfecske & Delichon urbicum & RV & 55
\end{tabular}

Füzikefélék - Phylloscopidae

Fitiszfüzike

Sisegő füzike

Csilpcsalpfüzike

Öszapófélék - Aegithalidae

$$
\text { Öszapó }
$$

Poszátafélék - Sylviidae

$$
\text { Barátposzáta }
$$

Kis poszáta

Ökörszemfélék - Troglodytidae

Ökörszem

Seregélyfélék - Sturnidae

$$
\text { Seregély }
$$

Rigófélék - Turdidae

$$
\text { Énekes rigó }
$$

Fenyőrigó

Fekete rigó

$$
\text { Léprigó }
$$

Légykapófélék - Muscicapidae

$$
\begin{gathered}
\text { Vörösbegy } \\
\text { Fülemüle } \\
\text { Kékbegy } \\
\text { Házi rozsdafarkú } \\
\text { Hantmadár }
\end{gathered}
$$

Phylloscopus trochilus
Phylloscopus sibilatrix
Phylloscopus collybita

Aegithalos caudatus

KÁ

$\begin{array}{cc}\text { Á } & 7 \\ \text { Á } & 10 \\ \text { Á } & 42\end{array}$

F, Á

F, Á

Curruca curruca

Troglodytes troglodytes

Á, T

Sturnus vulgaris

F, Á

Turdus philomelos

Á

Turdus pilaris

Á, T

$\mathrm{F}, \mathrm{A}$

Turdus viscivorus

KÁ

Erithacus rubecula

Á

Luscinia megarhynchos

F, Á

Luscinia svecica

F, Á

Phoenicurus ochruros

Oenanthe oenanthe

Á 16

Á 20


1. táblázat (folytatás). A Turai-gyepen 2010 és 2020 között megfigyelt madarak listája, azok státusza és a megfigyelési alkalmak száma. A státusz esetében az alábbi betűjelzéseket használjuk: $\mathrm{F}=$ fészkelö; $\mathrm{A}$ = rendszeres átvonuló; $\mathrm{KÁ}$ = kóborló átvonuló (kevesebb, mint öt megfigyelési adat); $\mathrm{T}$ = téli vendég; $\mathrm{RV}$ = rendszeres, az év bármely szakaszában megfigyelhető vendég, ami nem költ a területen.

\begin{tabular}{|c|c|c|c|}
\hline Faj & Tudományos név & Státusz & Adatok száma \\
\hline Cigánycsuk & Saxicola torquata & $\mathrm{F}, \mathrm{A}$ & 107 \\
\hline Rozsdás csuk & Saxicola rubetra & $\mathrm{F}, \mathrm{A}$ & 36 \\
\hline Szürke légykapó & Muscicapa striata & Á & 12 \\
\hline Kormos légykapó & Ficedula hypoleuca & Á & 4 \\
\hline \multicolumn{4}{|l|}{ Szürkebegyfélék - Prunellidae } \\
\hline Erdei szürkebegy & Prunella modularis & Á & 6 \\
\hline \multicolumn{4}{|l|}{ Verébfélék - Passeridae } \\
\hline Mezei veréb & Passer montanus & $\mathrm{F}$ & 143 \\
\hline \multicolumn{4}{|l|}{ Billegetőfélék - Motacillidae } \\
\hline Parlagi pityer & Anthus campestris & $\mathrm{F}, \mathrm{A}$ & 33 \\
\hline Havasi pityer & Anthus spinoletta & Á & 3 \\
\hline Réti pityer & Anthus pratensis & Á, T & 28 \\
\hline Erdei pityer & Anthus trivialis & Á & 40 \\
\hline Rozsdástorkú pityer & Anthus cervinus & Á & 18 \\
\hline Barázdabillegető & Motacilla alba & RV & 68 \\
\hline Sárga billegető & Motacilla flava & $\mathrm{F}, \mathrm{A}$ & 119 \\
\hline Citrombillegető & Motacilla citreola & KÁ & 2 \\
\hline \multicolumn{4}{|l|}{ Pintyfélék - Fringillidae } \\
\hline Erdei pinty & Fringilla coelebs & $\mathrm{F}, \mathrm{A}$ & 138 \\
\hline Fenyőpinty & Fringilla montifringilla & Á & 5 \\
\hline Kenderike & Linaria cannabina & Á & 22 \\
\hline Tengelic & Carduelis carduelis & RV & 140 \\
\hline Zöldike & Chloris chloris & $\mathrm{RV}$ & 65 \\
\hline Csicsörke & Serinus serinus & RV & 4 \\
\hline Csíz & Spinus spinus & Á & 5 \\
\hline Meggyvágó & $\begin{array}{l}\text { Coccothraustes } \\
\text { coccothraustes }\end{array}$ & KÁ & 1 \\
\hline
\end{tabular}

Sármányfélék - Emberizidae

Nádi sármány
Sarkantyús sármány
Citromsármány
Sordély

Emberiza schoeniclus
Calcarius lapponicus
Emberiza citrinella
Emberiza calandra

$\mathrm{F}$

KÁ 1

Á, T 6

160 faj

F $\quad 71$

5662 adat 
Pettyes vízicsibe (Porzana porzana)

2018-ban minden valószínűség szerint költött egy pár egy sekély vizü mocsaras részen. Jellegzetes hangját mindig ugyanarról a területről hallatta, illetve több esetben látni is lehetett a madarat.

Barna rétihéja (Circus aeroginosus)

A terület nádasaiban minden évben költ 1-3 pár.

Kék vércse (Falco vespertinus)

2012-ig rendszeresen költött egy pár a Natura 2000 területen található idős kőriserdőben. Azóta nem fészkel a területen, de a közelben fészkelö pár(ok)nak, illetve őszi időszakban a közelben gyülekező csapatok tagjainak a gyep fontos táplálkozóhelye.

Gulipán (Recurvirostra avosetta)

2010-ben, 2013-ban, 2017-ben és 2019-ben is költött a belvizes szántókon, azonban sikeresen kirepült fiatalokat csak 2017-ben és 2019-ben figyeltünk meg (mindkét esetben egy-egy fiatalt). Jellemzően mindegyik évben jóval több pár kezdte el a fészkelést, de a belvizek kiszáradása miatt a fiatalok a legtöbb esetben nem tudtak felnőni.

Gólyatöcs (Himantopus himantopus)

2010-ben, 2013-ban és 2019-ben is költött egy-egy pár a terület belvizes szántóin. 2013-ban egy, míg 2019-ben három fiatal repült ki, 2010-ből viszont nincs adatunk sikeres fészkelésről. A gulipánhoz hasonlóan jellemzően több pár is fészkelésbe kezd, de a vizek kiszáradása általában megsemmisíti a fészkeket. Jobban kötődik a mocsári növényzethez, mint a gulipán.

Piroslábú cankó (Tringa totanus)

2010-ben, 2013-ban és 2017-ben költött 1-5 pár a belvizes szántókon. A költések sikerességéről nincs információnk, de 2017-ben a június második felében megfigyelt kb. 20 példány arra utal, hogy mind az öt pár sikeresen repített fiatalokat.

\section{Sárszalonka (Gallinago gallinago)}

Eddig csak 2018-ban feltételeztük költését a gyep északi részén elterülő mocsaras területen, ahol áprilisban több madár is intenzíven nászrepült. Figyelembe véve azonban a faj költési idejét (Haraszthy 2019), valószínű, hogy a 2013 májusában megfigyelt madár is fészkelő pár tagja lehetett. 2018-ban előző ősszel levágott nádasban költhettek a madarak, ahol sekély vízállás, nádtorzsák és mocsári vegetáció volt a domináns. 
Réti fülesbagoly (Asio flammeus)

A faj 2014-es országos gradációja alkalmával a Turai-gyepen is megtelepedett legalább két pár. A költések sikerességéröl, így a kirepült fiatalokról sincs információnk, az öreg madarak azonban mindkét revírben február közepe és június vége között is a területen mozogtak.

Szalakóta (Coracias garrulus)

Mezőgazdasági munkások elbeszélése alapján a faj költhetett a területen az 1990-es években és a 2000-es évek elején, 2010-ben viszont már nem találkoztunk vele. 2016-ban ezért a gyep déli részén húzódó idős kőrisfasorra egy mesterséges fészekodút helyeztünk ki. 2016 júliusában egy gyürüs madár (a gyürü számát nem sikerült leolvasni) több alkalommal is elökerült a környező körbálákon, illetve az odútól kb. 50 méterre lévő idős nyárfák környékén. Július 28-án egy fiatal egyedet is láttunk, de az odúban ebben az évben egészen biztosan nem költött a faj. A következő évben június közepén két madár tartózkodott az odú körül, az egyiket a romániai Nagylak térségében jelölték fiatal madárként 2016. július 10-én. Az odúban két tojás volt, de ezek később bezápultak, mert az öreg madarak ismeretlen okból július elejére eltüntek a területről. 2018-ban aztán megtörtént a faj első sikeres költése is, hiszen ekkor két fiatal repült ki az odúból július közepén. 2019-ben és 2020-ban csupán egy alkalommal észleltük a fajt, költése nem volt.

Kékbegy (Luscinia svecica)

Első megfigyelését (2010. április) követően hosszú ideig nem észleltük a területen, azonban 2015-ben, 2017-ben, 2018-ban, 2019-ben és 2020-ban is előkerült egy-egy éneklő hím a gyep középső részén található nádasban. Párját csupán kétszer sikerült látni, 2019. július 1-jén és 2020. május 8-án, mindkét alkalommal az éneklő hím revírjében. Az évente megfigyelt példányok minden évben ugyanabban a jól körülhatárolható revírben énekeltek, ezért annak ellenére, hogy fészkét nem találtuk meg, egészen biztosan stabilan fészkel a faj a területen.

Nádi tücsökmadár (Locustella luscinioides)

Stabil, viszonylag nagyszámú fészkelő (kb. 10 pár) a terület aratatlan nádasaiban. Az állomány gyakorlatilag egyáltalán nem változott a kutatás évei során, a madarak jellemzően ugyanazokban a revírekben tartózkodtak, ahol a megelőző években.

Réti tücsökmadár (Locustella naevia)

2013-ban, 2016-ban, 2017-ben és 2020-ban feltételezhetően költött egy-egy pár a gyep középső, magas füvü, kevés náddal elegyes részén. Fészkét nem találtuk meg, de mivel a madarak mindegyik évben június végéig, július elejéig itt tartózkodtak, így költése igen valószínű. 
Kis örgébics (Lanius minor)

Egy pár minden évben költ a gyep déli részén húzódó idős kőrisfasoron. A térségben jelentősen csökkent az állománya a vizsgálati időszakban, ezért nem kizárt, hogy 2010 elött a Turai-gyep környékén is nagyobb számban fészkelt.

\section{Átvonuló és telelö madárfajok}

Az eddig megfigyelt 170 madárfaj közül 93 (55\%) csak az őszi és tavaszi vonuláskor, illetve a téli időszakban jelenik meg a területen. Az átvonuló és telelö fajok egy része minden évben előfordul, míg mások csak alkalmi kóborlónak számítanak. Az 1. táblázatban minden faj esetében feltüntettük a területre vonatkozó státuszát, illetve a megfigyelések számát. Néhány, a területre jellemző, természetvédelmi szempontból érdekes fajról részletesebben írunk.

Daru (Grus grus)

Kizárólag tavaszi adatai vannak a területről (március közepe-április vége). Elsősorban néhány példányos csapatokban szoktak táplálkozni a gyep belső, nyílt részein, de 2013 áprilisában azt is megfigyeltük, amint 200 példányos csapata éjszakázni húzott be a gyepre, míg 2020-ban nagy számban elhullajtott toll árulkodott arról, hogy a madarak itt éjszakázhattak. Gyakran még április végén is szem elé kerül néhány példány.

\section{Kék galamb (Columba oenas)}

Első példányai olykor már július legvégén is megfigyelhetők, a nagyobb csapatok érkezése azonban csak szeptember második felétől jellemző. Ettől kezdve egészen februárig, esetenként pedig március közepéig is itt maradhatnak. Legnagyobb csapata 100 példányból állt. A madarak általában a gyepen, illetve a környező tarlókon táplálkoznak.

Pacsirták, pityerek (Alaudidae, Motacillidae)

A terület fontos szerepet tölt be a mezei pacsirta (Alauda arvensis) és a réti pityer (Anthus pratensis) őszi gyülekezésében. Összel esetenként akár 40 példányos mezeipacsirta-csapatok is megpihenhetnek az ürmös foltokon, míg a réti pityer esetében 2012. október 26-án egy kb. 250 példányos csapat húzott be a területre éjszakázni. Mindkét faj kis számban át is telel a területen. A rozsdástorkú pityer (Anthus cervinus) kisebb számban ugyan, de tavasszal és ősszel is átvonul, míg a havasi pityernek (Anthus spinoletta) főként a tavaszi időszakból van néhány adata. 
Kiemelt növénytani értékek

A fejezetben a lőkösházi Turai-gyepen előforduló növények közül a védelem alatt álló, illetve a természetvédelmi szempontból regionális szinten értékes fajok kerülnek megemlítésre.

Sziki boglárka (Ranunculus lateriflorus)

Szikes laposok, szikes rétek pionír jellegü védett faja. A lőkösházi Turai-gyepen ritka-szórványos.

Koloncos legyezőfü (Filipendula vulgaris)

Regionálisan erösen megritkult, védendő faj, a regionális vöröslistán is szerepel (Sallainé Kapocsi et al. 2012). A Turai-gyepen ritka. Egy foltja található, a szikikocsord-állomány mellett.

Sziki kocsord (Peucedanum officinale)

A Tiszántúlra jellemző védett faj, ugyanakkor a tágabban vett Csanádi-háton (Csanád-Aradi-háton) mindössze erről a területről ismert fennmaradt állománya. Alföldi előfordulása kifejezetten kötődik a kocsordos-őszirózsás sziki magaskórós (Peucedano-Asteretum sedifolii) társuláshoz. A Turai-gyepen ritka, mindössze egy kis kiterjedésü, de sürü foltja található. Az állomány egyedszáma néhány száz tőre tehető. 2018. november 5-én megtaláltuk a sziki kocsordhoz kötődő fokozottan védett monofág rovarfaj, a nagy szikibagoly (Gortyna borelii lunata) hernyójának granulátumszerü nyomát is, amely szintén rendkívül fontos, eddig nem publikált értéke a területnek (vö.: Danyik 2015).

Erdélyi útifü (Plantago schwarzenbergiana)

Szikes rétek, ürmös szikespuszták bennszülött, védett faja. A Csanád-Aradi-hát területén csak erről a gyepről és Elek határából (Kertész 1999) ismert.

Réti őszirózsa (réti gerebcsin) (Aster sedifolius) (Syn.: Galatella sedifolia)

A kocsordos-őszirózsás sziki magaskórósok (Peucedano-Asteretum sedifolii) jellemző, védett faja. A jellemzően magasfekvésü Csanádi-háton azonban csak szórványos előfordulású. A Turai-gyepen gyakori.

Sziki üröm (Artemisia santonicum)

A szükebben vett Csanádi-háton nagyon ritka, mindössze a dombegyházi Jakabffy-gyepen ismert egy kis állománya (Csathó 2015). A korábban Arad vármegyéhez tartozó részeken Eleken (Kertész 1999) és Lőkösházán él - utóbbi település határában csak ezen a területen. A padkás szikesek (F1a) a kistájban kifejezetten ritka élőhelynek számítanak, a Turai-gyepen meglévő állományok az élőhelytípus legértékesebb képviselői közé tartoznak a Csanád-Aradi-háton.

Nyúlánk sárma (Ornithogalum brevistylum) (Syn.: Ornithogalum pyramidale)

Löszpusztagyepek védett faja. A jellemzően mélyebb fekvésü Turai-gyepen nem gyakori. 
Egypelyvás csetkáka (galléros csetkáka) (Eleocharis uniglumis)

Mélyebb fekvésủ szikes laposok védett faja. A Turai-gyepen gyakori.

\section{Diszkusszió}

Az agrárterületeken élő madárfajok fészkelő állománya Európa több részén is drasztikusan csökkent az elmúlt évtizedekben (Tucker és Heath 1994, Siriwardena et al. 1998, Golawski 2006). Magyarországon ez a csökkenés elsősorban a hosszú távú vonuló madárfajokat érintette, míg a rövid távú vonulók esetében gyakran növekvő állományról beszélhetünk (Szép et al. 2012). Az állománycsökkenés hátterében általában a mezőgazdasági művelés intenzifikációja, a vegyszerhasználat növelése és a korábbi kis parcellák egybefüggő földterületekké való összevonása áll (Wilson et al. 1997, Brickle et al. 2000, Chamberlain és Fuller 2000, Nagy et al. 2009). A kiváló talajadottságú földrajzi régiókban, így például Békés megye déli-délkeleti szegletében is a szántóföldi növénytermesztés arányaiban akár az összterület 90\%-át is érinti (Hevesi 2005), aminek következtében a területre jellemző élővilág általában csak szigetszerüen, élőhely-fragmentumokban maradhatott fenn. Kis kiterjedésük és fragmentált elhelyezkedésük miatt a természetvédelem számára ezen élőhelyek jogi védettsége általában nehezen oldható meg, annak ellenére, hogy az utóbbi években néhány esetben pozitív civil kezdeményezések is történtek ezen a téren (Balogh 2016, Bozó 2019). A dolgozatunkban bemutatott Turai-gyep is kiválóan példázza, hogy a területi védelem bármely kategóriája is hozzájárulhat egy értékes terület fennmaradásához és a térség biodiverzitásának megőrzéséhez. A terület jogilag nem védett, ám azáltal, hogy a Natura 2000 hálózat részét képezi, az elmúlt évtizedben sikerült megmenekülnie a művelésbe vonástól. Az ott gazdálkodók a pénzügyi támogatás hatására szakszerüen, az elóírásoknak megfelelő időpontokban kaszálják a terület füves részeit, így a talajon fészkelö fajok (pl. fürj, parlagi pityer - Anthus campestris) zavartalanul tudnak költeni. Az utóbbi években pedig olyan is elöfordult, hogy a száraz nádas részeken télen szárzúzóval vágták le a nádat. Ennek következtében több hektáros nyílt belvizes rétek alakultak ki, és ott tavasszal partimadarak százai pihentek meg és költöttek. Kiemelendő, hogy avas nádasok is megmaradtak, ami elengedhetetlen feltétele többek között a nádi énekesmadarak (pl. nádi tücsökmadár, cserregő nádiposzáta) megtelepedésének. Sajnálatos tény ugyanakkor, hogy a Turai-gyepen 2018-ban és 2019-ben is szükségtelen földmunkákat végeztek (árokásás, tárcsázás), amely ugyan csak kis területet érintett, de a még megmaradt természeti értékek degradálódása nem megengedhető. 
A 2010 és 2020 között itt megfigyelt fajok egy része a környező agrárterületeken is rendszeresen megfigyelhető (például a tövisszúró gébics - Lanius collurio, a cigánycsuk - Saxicola torquata, vagy éppen a sordély - Emberiza calandra; Bozó 2017b), azonban számos olyan fajt is sikerült észlelni, amely kifejezetten kötődik a természetes gyepekhez, mocsarakhoz. A gyep esetleges degradálódásával, felszántásával a térségben nagy valószínűséggel nem költene többek között a nyári lúd, a pettyes vízicsibe, a szalakóta, a kékbegy és a réti tücsökmadár, de talán a böjti réce (Spatula querquedula) és a nádi tücsökmadár sem. A Turai-gyep az itt átvonuló madarak számára is kulcsfontosságú pihenő- és táplálkozóhelyként szolgál, legyenek azok akár vízi-, ragadozó- vagy énekesmadarak. Elsősorban a tavaszi vonuláskor találnak a területen megfelelő belvizes foltokat, így elsősorban a február közepe és május vége közötti időszakban számít a gyep különösen fontos pihenőhelynek, de azok a fajok (pl. réti fülesbagoly, pacsirták, pityerek), amelyek a száraz szikes gyepekhez kötődnek, ősszel is nagy számban mutatkoznak itt. A fokozottan védett és kiemelt jelentőségü fajok mellett az elmúlt 11 év adatai arra is rávilágítanak, hogy azok a madárfajok, amelyek az agrárterületeken a termesztett növénykultúrák mozaikos elhelyezkedése miatt foltszerüen költenek (pl. fürj, sordély), itt koncentráltan, nagyobb számban élnek. Mindez azt is jelentheti, hogy ha a mezőgazdasági termelés még intenzívebbé válik, akkor a Turai-gyephez hasonló élőhelyszigetek bizonyos fajok ténylegesen utolsó mentsváraivá válhatnak.

A Turai-gyep számos botanikai értékkel is rendelkezik. A terület növénytani jelentőségét növeli, hogy a tágabban vett Csanádi-háton (Csanád-Aradi-hát) a karakteres szikes területek - föleg tiszántúli viszonylatban - meglehetősen ritkának számítanak, így több jelenlévő (a Tiszántúlon egyébként elterjedt) sziki növényfaj a kistájban ritkaság (Csathó 2015).

Az agrártájban tehát már önmagában egy ilyen élőhelysziget is fontos szerepet játszik a természeti értékek megőrzésében, azonban szerencsére több környékbeli település határában is vannak hasonló (bár kisebb kiterjedésü) élőhelyek, amelyek ugyancsak a Natura 2000 hálózat részét képezik. A Turai-gyeptől kb. 19 km-re délnyugati irányban található a dombegyházi Jakabffy-gyep, amely szintén szikes terület. Kiterjedése mintegy 36 hektár, és belvizes években tavaszonként itt is jelentős vízállások alakulnak ki. A Csathó (2015) által a Jakabffy-gyepről közölt madártani adatokat összevetve a Turai-gyep fajlistájával rendkívül nagy hasonlóságot láthatunk a két terület között. Nevezetesen mindkét terület elsősorban a tavaszi időszakban kínál megfelelő pihenő- és táplálkozóhelyet az átvonuló madarak számára, belvizes években a területek madártani jelentősége érezhetően megnövekszik.

Hasonló kiterjedésủ (37 hektár) a Battonya határában, a Turai-gyeptől kb. 25 km-re délnyugatra található Gulyagyep is, ahol azonban a mélyebb laposok kisebb 
kiterjedése miatt jóval kevesebb vízi- és partimadarat lehet megfigyelni (ezeket is általában csak átrepülöben; Csathó 2010). A belvizes területek kisebb kiterjedése mellett számos faj hiányának oka ezen a területen a belterület közvetlen szomszédságából adódó emberi zavarás is lehet. Párhuzamba lehet ugyanakkor állítani a két területen fészkelő gyakoribb fajokat, így például a fürjet, a cigánycsukot, a tövisszúró gébicset és a kis őrgébicset, ezek azonban elterjedtek az agrárterületeken is.

A Natura 2000 részét képezi, illetve a Körös-Maros Nemzeti Park törzsterülete a Kígyósi-puszta, amely a felsorolt területeknél ugyan jóval nagyobb kiterjedésű, ám élőhelyi adottságai hasonlók. A Kígyósi-puszta délkeleti része alig 15 km távolságra található a lőkösházi Turai-gyeptől. A mélyebben fekvő, belvízzel borított területek kiterjedése évente 300 és 500 hektár között változik, ezek kiváló pihenő-, táplálkozó- és fészkelőhelyként funkcionálnak a madarak számára (Marik 1998). A két terület madárvilága közt jelentős hasonlóságokat találhatunk, míg az eltérések (a megfigyelt fajok és az átvonuló egyedek, fészkelő párok magasabb száma a Kígyósi-pusztán) minden valószínűség szerint a Kígyósi-puszta nagyságrendekkel nagyobb területi kiterjedésével magyarázhatók. Érdemes megemlíteni, hogy azok a fajok, amelyek Lőkösházán fészkeltek az elmúlt évtizedben, kettő kivételével mind költöttek a Kígyósi-pusztán is 1977 és 1997 között (Marik 1998). A két kivétel a nyári lúd és a kékbegy, ami azért érdekes, mert valószínúleg mindkét faj számára volt megfelelő fészkelőhely a Kígyósi-pusztán is. A kékbegy esetében ugyanakkor megjegyzendő, hogy az ország bizonyos részein növekedett a faj állománya a 2000-es évek első évtizedében (Hadarics és Zalai 2008), ami akár más területek kolonizálást is eredményezhette ('így jelenhetett meg Lőkösházán és akár a Kígyósi-pusztán is). Egy további érdekességet is találhatunk a két terület fajlistájában, méghozzá a kendermagos réce (Mareca strepera) státuszát. Országos szinten rendszeresen átvonul a különféle vizes élőhelyeken, előnyben részesítve a dús hínárnövényzettel borított állóvizeket (Hadarics és Zalai 2008), ennek ellenére mindkét területen csak alkalmi kóborló, míg a Jakabffy-gyepről egyáltalán nincs is adata (Csathó 2015). Ennek valószínúleg az lehet az oka, hogy a térség nem esik bele a faj fő vonulási útvonalába.

Összegzésként elmondhatjuk, hogy a Turai-gyep számos, természetvédelmi szempontból értékes, védett vagy fokozottan védett állat- és növényfajnak szolgál otthonául. A Dél-Békéshez hasonló agrártájak esetében a mozaikos elhelyezkedésü, kis kiterjedésủ természetes élőhelyfoltok hálózatának fennmaradása nélkülözhetetlen bizonyos fajok regionális kipusztulásának elkerülése érdekében. Danyik (2018) szintén a térségben végzett, atracélcincérrel (Pilemia tigrina) kapcsolatos kutatásai rávilágítottak az élőhelyfragmentumok láncolatának fontosságára. Ha ugyanis az élőhelyeket fokozatosan felszámolják, és az élőhelyek láncolata megszakad, a különböző foltokban élő cincérpopulációk tagjai nem lesznek képesek 
eljutni az egyre távolabb kerülő többi populációhoz, ami idővel a helyi állomány kipusztulásához vezethet. A vonuló madarak esetében is rendkívül fontos az élöhelyek láncolata, hiszen a vonulási útvonalon bekövetkező élőhelyvesztés jelentős hatással lehet az ott megpihenő fajok állományára (Webster és Marra 2005, Xu et al. 2019). A Natura 2000 minősítés azonban lehet, hogy csak átmeneti védelmet jelent ezen élőhelyek számára, ezért minden ilyen élőhelyfragmentum esetén fontos lenne azok hivatalos védetté nyilvánítása is (helyi, esetleg országos védett természeti területté nyilvánítás), amelyet alulról jövő, civil kezdeményezések is megvalósíthatnak (http3).

Köszönetnyilvánítás - Szeretnénk kifejezni köszönetünket Bozóné Borbáth Erna részére, a madártani felmérések során nyújtott segítségéért. A szerzők köszönetüket fejezik ki Olajos Nikolettnek az angol nyelvü összefoglaló nyelvi lektorálásáért.

\section{Irodalomjegyzék}

Balogh, G. (2016): Kutatásaink és eredményeink Tótkomlóson. In: Balogh, G. (szerk.): Aki keres, talál... A Száraz-ér Társaság kutatásai 2011-2015 között. Száraz-ér Társaság Természetkutató és Környezetvédő Egyesület, Tótkomlós, pp. 6-8.

Bede, Á., Csathó, A. I. (2019): Complex characterization of kurgans in the Csanádi-hát region, Hungary. Tájökológiai Lapok 17(2): 131-145.

Bozó, L. (2017a): A Charadriiformes madárrend tagjainak vonulása és fészkelése Kevermesen és Lőkösházán. Állattani Közlemények 102(1-2): 25-49. https://doi.org/10.20331/ AllKoz.2017.102.1-2.25

Bozó, L. (2017b): Kevermes madárvilága. Dél-békési Természetvédelmi és Madártani Egyesület, Kevermes, $122 \mathrm{p}$.

Bozó, L. (2018): Dél-Békés természeti értékei. Magánkiadás, Kevermes, 199 p.

Brickle, N. W., Harper, D. G., Aebischer, N. J., Cockayne, S. H. 2000: Effects of agricultural intensification on the breeding success of corn buntings Miliaria calandra. Journal of Applied Ecology 37(5): 742-755. https://doi.org/10.1046/j.1365-2664.2000.00542.x

Chamberlain, D. E., Fuller, R. J., Bunce, R. G., Duckworth, J. C., Shrubb, M. (2000): Changes in the abundance of farmland birds in relation to the timing of agricultural intensification in England and Wales. Journal of Applied Ecology 37(5): 771-788. https://doi.org/10.1046/j.13652664.2000.00548.x

Csathó, A. [J.] (1986): A battonya-kistompapusztai löszrét növényvilága. Környezet-és Természetvédelmi Évkönyv 7: 103-115.

Csathó, A. J. 2005: A Battonya-tompapusztai löszpusztarét élővilága. Magánkiadás, Battonya, 129 p.

Csathó, A. I. (2009): A mezsgyék természetvédelmi jelentősége és védelmük időszerüsége. Természetvédelmi Közlemények 15: 171-181.

Csathó, A. I. (2010): A battonyai Gulyagyep élővilága. A Puszta 23: 201-257.

Csathó, A. I. (2015): A dombegyházi Jakabffy-gyep élővilága. A Puszta 25: 341-393.

Csathó, A. J., Csathó, A. I. (2009): A battonya-tompapusztai Külső-gulya flóralistája. Crisicum 5: $51-70$. 
Danyik, T. (2015): Nagy szikibagoly Gortyna borelii lunata. In: Deli, T., Danyik, T. (szerk.): A Körös-Maros Nemzeti Park állatvilága. Gerinctelenek. A Körös-Maros Nemzeti Park természeti értékei II. Körös-Maros Nemzeti Park Igazgatóság, Szarvas, pp. 338-339.

Danyik, T. (2018): Az atracélcincér (Pilemia tigrina) és élőhelyeinek természetvédelmi helyzetképe a Dél-Tiszántúlon. Crisicum 10: 169-192.

Deák, B., Tóthmérész, B., Valkó, O., Sudnik-Wójcikowska, B., Moysiyenko, I. I., Bragina, T. M., Apostolova, I., Dembicz, I., Bykov, N. I., Török, P. (2016): Cultural monuments and nature conservation: a review of the role of kurgans in the conservation and restoration of steppe vegetation. Biodiversity and Conservation 25(12): 2473-2490. https://doi.org/10.1007/s10531-016-1081-2

European Commission (2000a): Natura 2000. Managing our heritage. EU, Luxembourg.

European Commission (2000b): Managing Natura 2000 sites. The provisions of article 6 of the 'Habitats' Directive 92/43/CEE. EU, Luxembourg.

Evans, D. (2012): Building the European Union's Natura 2000 network. Nature Conservations 1: 11-26. https://doi.org/10.3897/natureconservation.1.1808

Gill, F., Donsker, D. (eds.) (2019): IOC World Bird List (v 9.2). https://doi.org/10.14344/IOC.ML.9.2

Golawski, A. (2006): Changes in numbers of some bird species in the agricultural landscape of eastern Poland. Ring 28(2): 127-133. https://doi.org/10.2478/v10050-008-0036-8

Hadarics, T., Zalai, T. (2008): Magyarország madarainak névjegyzéke. Nomenclator avium Hungariae. An annonated list of the birds of Hungary. Magyar Madártani és Természetvédelmi Egyesület, Budapest, 277 p.

Haraszthy, L. (2019): Sárszalonka Gallinago gallinago. In: Haraszthy, L. (szerk.): Magyarország fészkelö madarainak költésbiológiája. 1. kötet. Fácánféléktől a sólyomfélékig. Pro Vértes Nonprofit Kft., Csákvár, pp. 513-517.

Hevesi, J. (2005): Határ mentén. Békés Megyei Önkormányzat, Typografika Kft., Békéscsaba, 175 p.

Kertész, É. (1999): Elek növényvilága. Crisicum 2: 35-49.

Király, G. (szerk.) (2009): Új magyar füvészkönyv. Magyarország hajtásos növényei. Határozókulcsok. Aggteleki Nemzeti Park Igazgatóság, Jósvafö, 616 p.

Marik, P. (1998): A Szabadkígyósi Tájvédelmi Körzet madárvilága (1977-1997). A Puszta 15(1): 180-203.

Nagy, S., Nagy, K., Szép, T. (2009): Potential impact ofEU accession on common farmland bird populations in Hungary. Acta Ornithologica. 44(1): 37-44. https://doi.org/10.3161/000164509X464867

Sallainé Kapocsi, J., Jakab, G., Csathó, A. I., Penksza, K., Tóth, T. (2012): A Dél-Tiszántúl növényfajainak Vörös Listája. In: Jakab, G. (szerk.): A Körös-Maros Nemzeti Park növényvilága. A Körös-Maros Nemzeti Park természeti értékei I. Körös-Maros Nemzeti Park Igazgatóság, Szarvas, pp. 380-399.

Siriwardena, G. M., Baillie, S. R., Buckland, S. T., Fewster, R. M., Marchant, J. H., Wilson, J. D. (1998): Trends in the abundance of farmland birds: a quantitative comparison of smoothed Common Birds Census indices. Journal of. Applied Ecology 35(1): 24-43. https://doi.org/10.1046/ j.1365-2664.1998.00275.x

Szép, T., Nagy, K., Nagy, Zs., Halmos, G. (2012): Population trends of common breeding and wintering birds in Hungary, decline of longdistance migrant and farmland birds during 1999-2012. Ornis Hungarica 20(2): 13-63. https://doi.org/10.2478/orhu-2013-0007

Tucker, G. M., Heath, M. F. (1994): Birds in Europe: Their Conservation Status. Birdlife International, Cambridge, $600 \mathrm{p}$.

Webster, M. S., Marra, P. P. (2005): The importance of understanding migratory connectivity and seasonal interactions. In: Ricklefs, R. E. (ed.): Birds of Two Worlds: The Ecology and Evolution of Temperate-Tropical Migration. Johns Hopkins University Press, Baltimore, pp. 199-209. 
Wilson, J. D., Taylor, R., Muirhead, L. B. (1996): Field use by farmland birds in winter: an analysis of field type preferences using resampling methods. Bird Study 43(3): 320-332. https://doi. org $/ 10.1080 / 00063659609461025$

Xu, Y., Si, Y., Wang, Y., Zhang, Y., Prins, H. H., Cao, L., de Boer, W. F. (2019): Loss of functional connectivity in migration networks induces population decline in migratory birds. Ecological Applications 29(7): e01960. https://doi.org/10.1002/eap.1960

\section{Internetes források:}

http1: Agrárminisztérium: A Magyar Állami Természetvédelem hivatalos honlapja. http://www. termeszetvedelem.hu (Letöltés dátuma: 2020. január 2.)

http2: Magyar Madártani és Természetvédelmi Egyesület (2020): Natura 2000 adatbázis: Gyulaszabadkígyósi gyepek. http://www.mme.hu/natura-2000-teruletek/hukm20010 (Letöltés dátuma: 2020. január 2.)

http3: Bozó, L., Rozgonyi, J., Csathó, A. I. (2019): Bíztató lépések a mezsgyék növény- és állattani értékeinek védelméért Dél-Békésben. https://greenfo.hu/hir/biztato-lepesek-a-mezsgyeknoveny-es-allattani-ertekeinek-vedelmeert-del-bekesben/ (Letöltés dátuma: 2020. január 2.)

\section{The role of Natura 2000 sites in nature conservation in an agricultural landscape shown in the Turai-gyep lawn near Lőkösháza (SE Hungary)}

László Bozó ${ }^{1,2^{*}}$, János Rozgonyi ${ }^{2}$ \& András István Csathó ${ }^{3}$

${ }^{1}$ Eötvös Loránd University, Department of Systematic Zoology and Ecology, H-1117 Budapest, Pázmány Péter sétány 1/C, Hungary

${ }^{2}$ South Békés Nature Conservation Society, H-5744 Kevermes, Jókai u. 61, Hungary

${ }^{3}$ Independent researcher, H-5830 Battonya, Somogyi Béla u. 42/A, Hungary

*E-mail: bozolaszlo91@gmail.com

In the southern part of Békés County (Hungary), the proportion of agricultural areas is close to $90 \%$ of the total area, while the habitats of high conservation value are isolated in small fragments. In this paper, we present ornithological, botanical and entomological data from this geographical region, the Turai-gyep grassland Natura 2000 site near Lökösháza, from 2010 to 2020. During the fieldwork, a total of 170 bird species were detected in the area, 57 of which regularly or occasionally bred on the study site. There are many protected and highly protected species among the breeders that do not breed in other parts of the region. The occurrence of protected, otherwise rare species in the landscape has also been detected during botanical data collection, and at the same time, the presence of a highly protected insect species (Fisher's estuarine moth - Gortyna borelii lunata) also indicates the importance of the area. Comparing our findings with data from other Natura 2000 sites in the region, it is clear that the remaining natural habitats are of key importance to maintain the biodiversity of the area, and their disappearance would probably lead to the local extinction of several species.

Keywords: habitat fragments, agricultural fields, waterbirds, salines, Csanádi-hát region, Gortyna borelii lunata 